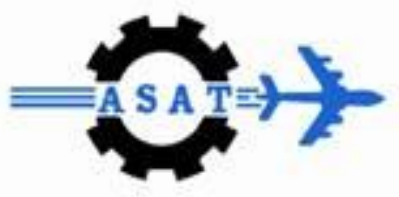

\title{
Application of the Convergence-Confinement Approach to Analyze the Rock-Lining Interaction in Tunnels (Case Study: Shimizu Tunnel)
}

\author{
Ayman A Mariee*, Adel M Belal ${ }^{* *}$, Ahmed El-Desouky ${ }^{* *}$
}

\begin{abstract}
The Convergence-Confinement approach is a procedure in which the ground-liner interaction is analyzed by considering the behavior of the ground and the lining independently. This method enables calculation of average radial pressure applied to the support by the intersection of two curves representing the radial stresses as a function of radial strain, one for the ground and the other for the liner. This paper discusses the application of the Convergence-Confinement method of tunnel analysis to rock masses that satisfies the Hoek-Brown failure criterion. The Shimizu Tunnel has been studied using this method to analyze the structural interaction between rock and different types of individual support systems such as; steel ribs, shotcrete, rock bolts and compound systems of these supports. The equations that govern the behavior of the rock-support interaction are given through two basic components of the Convergence-Confinement method which are, Ground Reaction Curve (GRC) and Support Characteristics Curve (SCC). According to the analytical results, a comparison has been conducted between the different support systems according to the maximum capacity pressure of the support and the estimated lining load based on the Convergence-Confinement method. The value of this load depends on the timing of lining installation and consequently the value of the ground radial displacement due to the releasing of stresses.
\end{abstract}

Keywords: Convergence-Confinement approach, Ground Reaction Curve, Rock bolts, Shotcrete, Structural interaction, Support Characteristics Curve.

\section{Introduction}

Controlling ground-lining interaction is one of the most critical processes during the implementation of tunneling projects. Some of the design and construction decisions during these projects are very critical to reduce the ground movements around the excavated tunnel. These movements have a direct effect on the tunnel stability and the design load of the lining system. Many lining systems have been used to support tunnels opening. Concrete segments, shotcrete, rock bolts, composite sections of steel and shotcrete, steel ribs and shotcrete and rock bolts are examples of the commonly used tunnel linings.

Choice of the appropriate lining system depends mainly on the geological conditions, ground stiffness, configuration of the tunnel and the in-situ stress field around the opening.

\footnotetext{
* Syrian Department of Armed Forces

** Egyptian Armed Forces
} 
In rock tunnels, the quality of the rock mass is an important factor to determine the suitable lining system. For moderately to hard homogeneous rock, a thin shotcrete thickness is sufficient to protect the rock surface, while in case of poor highly jointed rock, a stiffer lining system is needed according to the presence of joints, folds, faults and separated blocks. The main aim of this research is to investigate the behavior of the ground-lining interaction using the Convergence-Confinement approach.

\section{Case Study: Shimizu Tunnel}

The Shimizu Tunnel No. 3 located along Japan's Tomei-Meishin Expressway (Tomei II), The $1.1 \mathrm{~km}$ long Shimizu tunnel No. 3, was completed in Japan in 1988. The excavated diameter of the Shimizu Tunnel was $7.5 \mathrm{~m}$, advanced using Tunnel Boring Machines (TBMs).as shown in Figure. 1

\subsection{Subsurface Profile and Geotechnical Properties}

The ground at the site of Shimizu Tunnel No. 3 is composed of soft sedimentary rock formations, and a geological longitudinal section along is shown in Figure 2. There are five rock formations, and the main rock formation is the weathered soft sandstone of the late Miocene and Pliocene.

\subsection{Lining System}

Choosing lining system for a specific tunnel depends on the excavation technology, which is used for tunnel construction Support systems used in Shimizu Tunnel No. 3 (Japan Highways, 1998 Shotcrete $20 \mathrm{~cm}$, and $\mathrm{H} 200$ steel arches at a spacing of 1.0 m.and $6.0 \mathrm{~m}$ long rock bolts installed at a circumferential spacing of $1.2 \mathrm{~m}$.

\subsection{Ground Reaction Curve (GRC)}

The Ground Reaction Curve (GRC) for sandstone can be constructed using the elasto-plastic solution for circular opening subject to uniform far-field stresses and uniform internal pressure by using equations (1:14) as proposed by Carranza-Torres and Fairhurst (2000). Table 1 contains the data required for these calculations.

$$
\begin{gathered}
\mathrm{m}_{\mathrm{b}}=\mathrm{m}_{\mathrm{i}} \exp \left(\frac{\mathrm{GSI}-100}{28}\right) \\
\mathrm{P}_{\mathrm{i}}=\frac{\mathrm{p}_{\mathrm{i}}}{\mathrm{m}_{\mathrm{b}} \sigma_{\mathrm{ci}}}+\frac{\mathrm{s}}{\mathrm{m}_{\mathrm{b}}^{2}} \\
\mathrm{~S}_{\circ}=\frac{\sigma_{\circ}}{\mathrm{m}_{\mathrm{b}} \sigma_{\mathrm{ci}}}+\frac{\mathrm{s}}{\mathrm{m}_{\mathrm{b}}^{2}} \\
\mathrm{P}_{\mathrm{i}}^{\mathrm{cr}}=\frac{1}{16}\left(1-\sqrt{1+16 \mathrm{~S}_{\mathrm{o}}}\right)^{2} \\
\mathrm{p}_{\mathrm{i}}^{\mathrm{cr}}=\left(\mathrm{P}_{\mathrm{i}}^{\mathrm{cr}}-\frac{\mathrm{s}}{\mathrm{m}_{\mathrm{b}}^{2}}\right) \mathrm{m}_{\mathrm{b}} \sigma_{\mathrm{ci}} \\
\mathrm{s}=\exp \left(\frac{\mathrm{GSI}-100}{9}\right)
\end{gathered}
$$




$$
\begin{gathered}
\mathrm{a}=0.65-\left(\frac{\mathrm{GSI}}{200}\right) \\
\mathrm{u}_{\mathrm{r}}^{\mathrm{el}}=\left(\frac{\sigma_{\circ}-\mathrm{p}_{\mathrm{i}}}{2 \mathrm{G}_{\mathrm{rm}}}\right) \mathrm{R} \\
\mathrm{G}_{\mathrm{rm}}=\frac{\mathrm{E}_{\mathrm{rm}}}{2(1+v)} \\
\mathrm{Erm}=1000 \mathrm{C}\left(\sigma_{\mathrm{ci}}\right) 10^{(\mathrm{GSI}-10) / 40} \\
\mathrm{R}_{\mathrm{pl}}=\operatorname{Re} \mathrm{xp}\left[2\left(\sqrt{\mathrm{P}_{\mathrm{i}}^{\mathrm{cr}}}-\sqrt{\mathrm{P}_{\mathrm{i}}}\right)\right] \\
\mathrm{K}_{\psi}-1 \\
\left.\mathrm{~K}_{\psi}+1 \frac{2}{\mathrm{~K}_{\psi}+1}\left(\frac{\mathrm{R}_{\mathrm{pl}}}{\mathrm{R}}\right)^{\mathrm{K}_{\psi}+1}+\frac{1-\sin \psi}{4\left(\mathrm{~S}_{\circ}-\mathrm{P}_{\mathrm{i}}^{\mathrm{cr}}\right.}\right) \\
\left.\frac{1}{\mathrm{~S}_{\circ}-\mathrm{P}_{\mathrm{i}}^{\mathrm{cr}}}\right]\left[\left(\mathrm{K}_{\psi}+1\right) \ln \left(\frac{\mathrm{R}_{\mathrm{pl}}}{\mathrm{R}}\right)-\left(\frac{\mathrm{R}_{\mathrm{pl}}}{\mathrm{R}}\right)^{\mathrm{K}_{\psi}+1}+1\right] \\
\mathrm{G}_{\mathrm{rm}}^{\mathrm{cr}}=\left[\frac{1-2 v}{2} \frac{\sqrt{\mathrm{P}_{\mathrm{i}}^{\mathrm{cr}}}}{\mathrm{S}_{\circ}-\mathrm{P}_{\mathrm{i}}^{\mathrm{cr}}}+1\right]\left(\frac{\mathrm{R}_{\mathrm{pl}}}{\mathrm{R}}\right)^{2}+\frac{1-}{4\left(\mathrm{~S}_{\circ}\right.} \\
-\frac{1-2 v}{2} \frac{\sqrt{\mathrm{P}_{\mathrm{i}}^{\mathrm{cr}}}}{\mathrm{S}_{\circ}-\mathrm{P}_{\mathrm{i}}^{\mathrm{cr}}}\left[2 \ln \left(\frac{\mathrm{R}_{\mathrm{pl}}}{\mathrm{R}}\right)+1\right]
\end{gathered}
$$

Table 1 Required Data for Constructing the GRC.

\begin{tabular}{|l|l|}
\hline Radius of the tunnel $(\mathrm{R})$ & $7.5 \mathrm{~m}$ \\
\hline Unit weight for bedrock $(\gamma)$ & $25 \mathrm{KN} / \mathrm{m}^{3}$ \\
\hline Poisson's ratio $(\tilde{\mathrm{o}})$ & 0.3 \\
\hline Geotechnical Strength Index (GSI) & 40 \\
\hline Unconfined compressive strength $(\sigma \mathrm{ci})$ & $75 \mathrm{MPa}$ \\
\hline $\mathrm{m}_{\mathrm{i}}($ dimensionless parameter for intact rock) & 19 \\
\hline Shear modulus $\left(\mathrm{G}_{\mathrm{rm}}\right)$ & $1873.084 \mathrm{Mpa}$ \\
\hline Coefficient of lateral pressure $\left(\mathrm{k}_{0}\right)$ & 0.83 \\
\hline
\end{tabular}

where:

$m_{b}$ : dimensionless parameter for rock mass depends on both the intact rock parameter $m_{i}$ and the GSI value.

mi: dimensionless parameter of intact rock, the value of which depends on the type of rock being tested.

GSI: Geotechnical Strength Index.

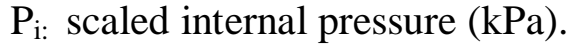


$\mathrm{p}_{\mathrm{i}}$ : uniform internal pressure $(\mathrm{kPa})$

$\sigma_{\text {ci: }}$ unconfined compressive strength $(\mathrm{kPa})$.

$\sigma_{\circ}$ : far-field stress $(\mathrm{kPa})$.

$\mathrm{S} \circ$ : scaled far-field stress $(\mathrm{kPa})$

$\mathrm{p}_{\mathrm{i}}^{\mathrm{cr}}$ : critical internal pressure $(\mathrm{kPa})$.

$\mathrm{P}_{i}^{\mathrm{cr}}$ : scaled critical pressure $(\mathrm{kPa})$.

$\mathrm{u}_{\mathrm{r}}^{\mathrm{el}}$ : radial displacement in the elastic part of the GRC (mm).

$\mathrm{u}_{\mathrm{r}}^{\mathrm{pl}}$ : radial displacement in the plastic part of the GRC $(\mathrm{mm})$.

$\mathrm{G}_{\mathrm{rm}}$ rock mass shear modulus $(\mathrm{kPa})$.

$\mathrm{E}_{\mathrm{rm} \text { : }}$ rock mass modulus (MPa).

$v$ : Poisson's ratio.

$\mathrm{R}$ : tunnel radius $(\mathrm{m})$.

$\mathrm{R}_{\mathrm{pl}}$ : radius of the plastic zone (m).

$K_{\Psi}$ : dilation angle, $\left(K \Psi=1\right.$ for $\Psi=0$ and $K_{\Psi}=3$ for $\left.\Psi=30\right)$.

s: dimensionless parameter depends on GSI which satisfies equation (6) for GSI $\geq 25$, for GSI $<25 \mathrm{~s}=0$.

a: dimensionless parameter depends on GSI which satisfies equation (7) for GSI $<25$, for GSI $\geq 25 \mathrm{a}=0$.

For equation (10):

$$
\begin{array}{ll}
\mathrm{C}\left(\sigma_{\mathrm{Ci}}\right)=1 & \text { if } \sigma_{\mathrm{ci}} \geq 100 \mathrm{MPa} \\
\mathrm{C}\left(\sigma_{\mathrm{Ci}}\right)=\left(\sigma_{\mathrm{Ci}} / 100\right)^{1 / 2} & \text { if } \sigma_{\mathrm{ci}} \leq 100 \mathrm{MPa}
\end{array}
$$

The GRC for the sandstone is constructed in the following analysis, considering the maximum overburden height of hard layer is equal to $80 \mathrm{~m}$, the maximum overburden pressure is calculated as the product of unit weight $\gamma$ by depth $\mathrm{h}$ and it is found to be $1.83 \mathrm{Mpa}$.

The GRC shown in Figure 3. Illustrates the critical pressure value $\mathrm{p}_{\mathrm{i}}^{\mathrm{cr}}=0.033 \mathrm{MPa}$, which marks the transition from elastic to plastic behavior of the rock-mass and a maximum plastic zone having $\mathrm{R}_{\mathrm{pl}}=7.58 \mathrm{~m}$. The calculated maximum closure (i.e., the radial displacement) $\mathrm{u}_{\mathrm{r}}^{\max }=4.05 \mathrm{~mm}$ at zero internal pressure (i.e., the tunnel is unsupported). The previous results were evaluated for the value of the coefficient of lateral earth pressure equal to $\left(\mathrm{k}_{\circ}=0.83\right)$.

\subsection{Support Characteristics Curve (SCC)}

The Support Characteristics Curve (SCC) has been constructed using three support systems steel ribs, shotcrete, and rock bolts.

\subsubsection{Support Characteristic Curve for steel ribs}

The maximum pressure $\left(\mathrm{p}_{\mathrm{s}}{ }^{\mathrm{max}}\right)$ sustainable from the steel ribs and the elastic stiffness (Ks) of a closed circular steel ribs is given by the following simplified expression after eliminating the effect of timber lagging:

where:

$$
\begin{array}{r}
\mathrm{p}_{\mathrm{s}}^{\max }=\frac{3}{2} \frac{\sigma_{\mathrm{ys}} \mathrm{A}_{\mathrm{s}}}{\mathrm{SR}} \\
\frac{1}{\mathrm{~K}_{\mathrm{s}}}=\frac{\mathrm{SR}^{2}}{\mathrm{E}_{\mathrm{s}} \mathrm{A}_{\mathrm{s}}}
\end{array}
$$


$\mathrm{P}_{\mathrm{S}}^{\max }$ : maximum pressure $(\mathrm{MPa})$

$\sigma_{y s}$ : yield strength of the steel $(\mathrm{MPa})$

A: cross-sectional area of the section $\left(\mathrm{m}^{2}\right)$

$\mathrm{S}$ : steel set spacing along the tunnel axis $(\mathrm{m})$

$\mathrm{R}$ : tunnel radius $(\mathrm{m})$

Ks: elastic stiffness

$\mathrm{E}_{\mathrm{s}}$ : young's modulus of steel $(\mathrm{MPa})$

The SCC shown in Figure 4. Illustrates the maximum calculated pressure (psmax) is 0.254 $\mathrm{MPa}$ and the calculated elastic stiffness of steel ribs (Ks) is $19.017 \mathrm{MPa} / \mathrm{m}$. The maximum calculated radial displacement at that moment of collapse after the full yielding of support $\operatorname{system}\left(\mathrm{u}_{\mathrm{r}}{ }^{\mathrm{max}}\right)$ is $0.25 \mathrm{~mm}$.

\subsection{Application of Convergence-Confinement Approach}

The interaction between the sandstone and the support system takes place after the installation of the support system. During the advance of the tunnel, the sandstone and the support system deform together and the support system receives part of the load that the tunnel face had been carrying previously before installing the support system. Once the TBM has moved ahead, the sandstone and the support system reach equilibrium and the support system carries the final load or design load $\left(\mathrm{p}_{\mathrm{s}}{ }^{\mathrm{D}}\right)$, which is indicated by point $\left(\mathrm{D}_{\mathrm{s}}\right)$ as shown in Figure 5 . The values of $\mathrm{p}_{\mathrm{s}}{ }^{\mathrm{D}}$ for steel ribs in case of $\left(\mathrm{k}_{\circ}=0.83\right)$, is $0.034 \mathrm{MP}$. At this time the effect of the face has disappeared and the ground had converged by the final amount $\left(\mathrm{u}_{\mathrm{r}}^{\mathrm{D}}\right)$. The values of $\mathrm{u}_{\mathrm{r}}^{\mathrm{D}}$ for steel ribs in case of $\left(\mathrm{k}_{\circ}=0.83\right)$ is $0.09 \mathrm{~mm}$. This deformation is the value of the radial convergence of the tunnel wall which resulted from the releasing of stresses before the start of the ground interaction with the support system.

\subsection{Support Characteristic Curve for shotcrete}

The structural behavior of shotcrete lining system is evaluated by using Equations $(17,18)$ to provide the maximum pressure that the shotcrete can sustain before collapse $\left(\mathrm{p}_{\mathrm{s}}{ }^{\mathrm{max}}\right)$ and the elastic stiffness (Ks),

$$
\begin{gathered}
\mathrm{p}_{\mathrm{s}}{ }^{\max }=\frac{\sigma_{\mathrm{cc}}}{2}\left[1-\frac{\left(\mathrm{R}-\mathrm{t}_{\mathrm{c}}\right)^{2}}{\mathrm{R}^{2}}\right] \\
\mathrm{K}_{\mathrm{S}}=\frac{\mathrm{E}_{\mathrm{c}}}{\left(1-v_{\mathrm{c}}\right) \mathrm{R}} \frac{\mathrm{R}^{2}-\left(\mathrm{R}-\mathrm{t}_{\mathrm{c}}\right)^{2}}{\left(1-2 v_{\mathrm{c}}\right) \mathrm{R}^{2}+\left(\mathrm{R}-\mathrm{t}_{\mathrm{c}}\right)^{2}}
\end{gathered}
$$

where:

$\sigma_{\mathrm{cc}}$ : unconfined compressive strength of the shotcrete (MPa).

$\mathrm{E}_{\mathrm{c}}$ : Young's modulus of shotcrete (MPa).

$v_{\mathrm{c}}$ : Poisson's ratio the shotcrete.

$\mathrm{t}_{\mathrm{c}}$ : thickness of shotcrete $(\mathrm{m})$.

$\mathrm{R}$ : tunnel radius $(\mathrm{m})$.

Table 2. Presentes the required data for these calculations. The shotcrete of $20 \mathrm{~cm}$ thickness can withstand a Pressure $\left(\mathrm{p}_{\mathrm{s}}{ }^{\mathrm{max}}\right)$ is $0.928 \mathrm{MPa}$ before collapse,. The calculated elastic stiffness of shotcrete $(\mathrm{Ks})$ is $116.342 \mathrm{MPa} / \mathrm{m}$. The maximum calculated radial $\left(\mathrm{U}_{\mathrm{r}}{ }^{\mathrm{max}}\right)$ is $6.7 \mathrm{~mm}$ displacement at the moment of collapse after the full yielding of the shotcrete Figure. 3 shown the Support characteristic curve shotcrete. 
Table 2 Required data for constructing SCC for shotcrete lining

\begin{tabular}{|l|l|}
\hline Property & Value \\
\hline$\sigma_{c c}$ & $35.3 \mathrm{MPa}$ \\
\hline$E_{c}$ & $18000 \mathrm{MPa}$ \\
\hline$v_{c}$ & 0.25 \\
\hline$t_{c}$ & $0.20 \mathrm{~m}$ \\
\hline$R$ & $7.5 \mathrm{~m}$ \\
\hline
\end{tabular}

The interaction between the sandstone and the shotcrete lining (thickness $20 \mathrm{~cm}$ ) will take place directly after lining of shotcrete is sprayed. During the advance of the tunnel the sandstone and the shotcrete deform together and the shotcrete receives part of the load that the tunnel face had been carrying previously before shotcreting.

Once the tunnel face has moved ahead far enough, the sandstone and the shotcrete is in equilibrium and the shotcrete carries the final load or design load $\mathrm{p}_{\mathrm{s}}{ }^{\mathrm{D}}$ is $0.034 \mathrm{MPa}$, which is indicated by point $\left(D_{c}\right)$ in Figure 6 . At that time the effect of the face has disappeared and the shotcrete and the ground have converged together by the final amount of about $u_{r}{ }^{D}$ is 0.59 $\mathrm{mm}$.

\subsection{Support Characteristic Curve for rock bolts}

Assuming that the bolts are equally spaced in circumferential direction, the maximum support pressure $\left(\mathrm{p}_{\mathrm{s}}^{\mathrm{max}}\right)$ provided by the support system and the elastic stiffness (Ks), can be evaluated using following equations.

$$
\begin{gathered}
\mathrm{p}_{\mathrm{s}}{ }^{\max }=\frac{\mathrm{T}_{\mathrm{bf}}}{\mathrm{s}_{\mathrm{c}} \mathrm{s}_{1}} \\
\frac{1}{\mathrm{~K}_{\mathrm{s}}}=\mathrm{s}_{\mathrm{c}} \mathrm{s}_{1}\left[\frac{4 \mathrm{~L}}{\pi \mathrm{d}_{\mathrm{b}}{ }^{2} \mathrm{E}_{\mathrm{s}}}+\mathrm{Q}\right]
\end{gathered}
$$

where:

$\mathrm{d}_{\mathrm{b}}$ : bolt diameter $(\mathrm{m})$.

L: free length of the bolt $(\mathrm{m})$.

$\mathrm{T}_{\mathrm{bf}}$ : ultimate load obtained from a pull-out test $(\mathrm{MN})$.

Q: deformation load constant for the bolt and the head $(\mathrm{m} / \mathrm{MN})$.

Es: Young's modulus for bolt (MPa).

Sc: circumferential bolt spacing, $\left(s c=2 \Pi R / n_{b}\right.$, where $n_{b}$ is the total number of equally spaced bolts installed in cross section. (m)

$\mathrm{S}_{1}$ : longitudinal bolt spacing in $(\mathrm{m})$.

Table 3. Presentes the required data for these calculations. The SCC of rock bolts as shown in Figure 7. illustrates the maximum calculated pressure $\left(\mathrm{p}_{\mathrm{s}}{ }^{\max }\right)$ is $0.133 \mathrm{Mpa}$, and the calculated elastic stiffness of the rock bolts $(\mathrm{Ks})$ is $5.796 \mathrm{MPa} / \mathrm{m}$. The maximum calculated radial displacement at the moment of collapse after the full yielding of the rock bolts is $\left(u_{r}{ }^{\max }\right)$ is $22.23 \mathrm{~mm}$. 
Table 3 Required Data for Constructing SCC for Rock Bolts Lining.

\begin{tabular}{|l|l|}
\hline Property & Value \\
\hline $\mathrm{d}_{\mathrm{b}}$ & $0.022 \mathrm{~m}$ \\
\hline $\mathrm{L}$ & $3 \mathrm{~m}$ \\
\hline $\mathrm{T}_{\mathrm{bf}}$ & $0.196 \mathrm{MN}$ \\
\hline $\mathrm{Q}$ & $0.042 \mathrm{~m} / \mathrm{MN}$ \\
\hline $\mathrm{E}_{\mathrm{s}}$ & $210 \times 10^{3} \mathrm{MPa}$ \\
\hline $\mathrm{S}_{\mathrm{c}}$ & $3.14 \mathrm{~m}$ \\
\hline $\mathrm{S}_{\mathrm{l}}$ & $1 \mathrm{~m}$ \\
\hline
\end{tabular}

The values $\left[\mathrm{d}_{\mathrm{b}}, \mathrm{L}, \mathrm{T}_{\mathrm{bf}}, \mathrm{Q}\right]$ determined for expansion shell bolts in field tests, which depend on the rock type. The radial displacement of the rock bolts is considered from the value $u_{r}$ is $3.0 \mathrm{~mm}$, which is the value of the radial convergence of the tunnel wall which associated with the release of stresses before the rock bolts activation.

\subsection{Compound Effect of Support Systems}

If more than one of the support systems are installed as composite lining, their combined effect can be determined by adding the elastic stiffnesses for each of the individual supports. This has the effect of increasing the total elastic stiffness of the whole system. Consider for example, the case in which two supports characterized by maximum pressure $\mathrm{p}_{\mathrm{s} 1}{ }^{\max }$ and $\mathrm{p}_{\mathrm{s} 2}{ }^{\max }$ and elastic stiffnesses $\mathrm{K}_{\mathrm{s} 1}$ and $\mathrm{K}_{\mathrm{s} 2}$, respectively are installed in a section of tunnel. The stiffnesses $\mathrm{K}_{\mathrm{s}}$ for the two systems acting together can be computed as following:

$$
\mathrm{K}_{\mathrm{S}}=\mathrm{K}_{1}+\mathrm{K}_{2}
$$

This value is assumed to remain valid until one of the two supports achieves its maximum possible elastic deformation $\mathrm{u}_{\mathrm{r}}{ }^{\max }$ computed as:

$$
\begin{gathered}
\mathrm{u}_{\mathrm{r} 1}{ }^{\max }=\frac{\mathrm{p}_{\mathrm{s} 1}{ }^{\max }}{\mathrm{K}_{\mathrm{s} 1}} \\
\mathrm{u}_{\mathrm{r} 2}{ }^{\max }=\frac{\mathrm{p}_{\mathrm{s} 2}{ }^{\max }}{\mathrm{K}_{\mathrm{S} 2}} \\
\mathrm{u}_{\mathrm{r}}{ }^{\max }=\mathrm{u}_{\mathrm{r} 1}{ }^{{ }^{\max }}+\mathrm{u}_{\mathrm{r} 2}{ }^{\max }
\end{gathered}
$$

The combined support system is assumed to fail at that point. The support with the lowest value of $\mathrm{u}_{\mathrm{r}}{ }^{\max }$ determines the maximum support pressure available for the two supports acting together because if one assumes that the collapse of the support system coincides with collapse of the weakest element, so the maximum support pressure that the system can sustain before collapse is computed as follows:

$$
\begin{array}{r}
\mathrm{p}_{\mathrm{s}}{ }^{\max }=\mathrm{u}_{\mathrm{r}, \min }{ }^{\max } \mathrm{K}_{\mathrm{s}} \\
7 / 11
\end{array}
$$




\section{Support Characteristics Curve for Different Compound Support Systems}

This type is divided to rock bolts and steel ribs as primary lining, which is installed after ground convergence by $0.5 \mathrm{~mm}$. The results of this type of support system are listed in Table 4. In addition, the table presents the field measurements. The SCC is shown in Figure 8.

Table 4 Results of Shotcrete and Steel Ribs and Rock Bolts Support System.

\begin{tabular}{|l|l|l|l|l|}
\hline Method & $\mathrm{P}_{\mathrm{s}}^{\max }(\mathrm{MPa})$ & $\mathrm{p}_{\mathrm{s}}^{\mathrm{D}}(\mathrm{MPa})$ & $\mathrm{u}_{\mathrm{r}}^{\max }(\mathrm{mm})$ & $\mathrm{u}_{\mathrm{r}}^{\mathrm{D}}(\mathrm{mm})$ \\
\hline $\begin{array}{l}\text { Convergence } \\
\text { Method }\end{array}$ & 1.125 & 0.033 & 3.43 & 1.1 \\
\hline $\begin{array}{l}\text { Field } \\
\text { Measurement }\end{array}$ & 1.4 & 0.045 & 4.0 & 1.35 \\
\hline $\begin{array}{l}\text { Difference } \\
(\%)\end{array}$ & $19 \%$ & $27 \%$ & $14 \%$ & $18 \%$ \\
\hline
\end{tabular}

\section{Conclusions}

Based on the work presented in this paper, the following could be concluded:

- The paper presented a comparison between the different support systems according to the maximum capacity pressure of the support and the lining load, which result from the point of intersection between the GRC and SCC (i.e., the equilibrium position).

- Results of the analysis suggest that the shotcrete lining is the better support system as it yielded the highest value of maximum capacity pressure $(0.928 \mathrm{MPa})$ of the support in case of using the Roadheader machine.

- This value of maximum capacity pressure is $73 \%$ and $86 \%$ higher than those values obtained when using steel ribs and rock bolts, respectively.

- In case of using compound systems, the maximum capacity pressure will be increased and the final radial displacement of the support systems will be decreased.

- The convergence method resulted in lower values compared to the field measurements. For most obtained results, the percentage of difference is less than $20 \%$.

\section{References}

[1] Carranza-Torres, C. and Fairhurst, C. (2000), "Application of The ConvergenceConfinement Method of Tunnel Design to Rock Masses that Satisfy The Hoek-Brown Failure Criterion."

[2] Sotirios S. Vardakos, Marte S. Gutierrez, Nick R. Barton " Back-analysis of Shimizu Tunnel "

[3] Lama and Vutukuri (1978) and Goodman (1980)." Engineering Properties of Soil and Rock "

[4] Bieniawski, Z. T., " Engineering Classification of Jointed Rock Masses", The Civil Engineer in South Africa, South Africa Institution of Civil Engineers, Transvaal, South Africa, December (1973), p.335-343 , (Quoted from Golder Associates, "Tunnelling Technology", 1979). 
[5] Carranza-Torres, C. and Fairhurst, C., "Application of The Convergence-Confinement Method of Tunnel Design to Rock Masses That Satisfy The Hoek-Brown Failure Criterion.”, Magazine, Tunnelling and Underground Space Technology, Vol. 15, No. 2, Published by Elsevier Science Ltd., (2000),

[6] Deere, D. U., Peck, R. B., Monseesn, J. E. and Schmidt, B., “ Design of Tunnel Liners and Support Systems", Report for U.S. Department of Transportation, OHSGT Contract 3-0152, No. PB 183799, NTIS, Spring Field, Virginia, U.S.A., (1969), p.278, (Quoted from Golder Associates, "Tunneling Technology", 1979).

[7] Barton, N.R., Lien, R., Lunde, J., 1974. Engineering classification of rock mass for the design of tunnel support.

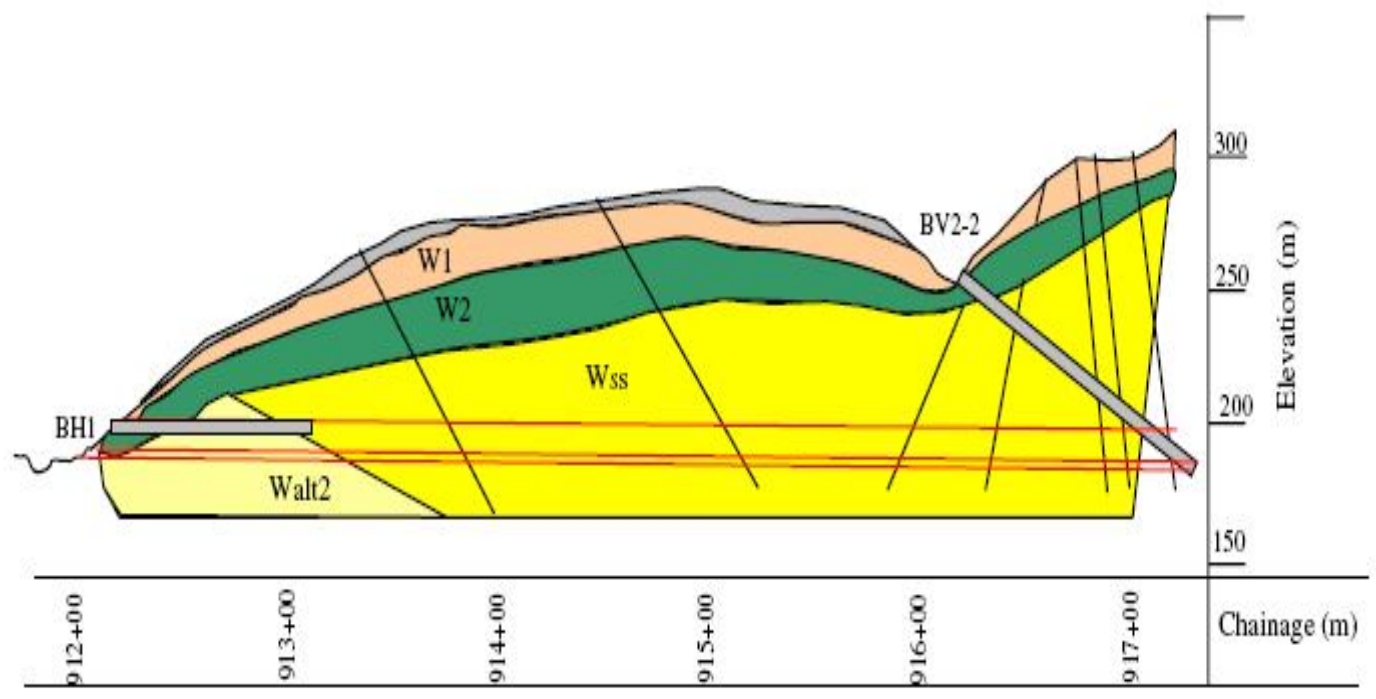

Fig 1. Longitudinal geological section along the western sector tunnel.

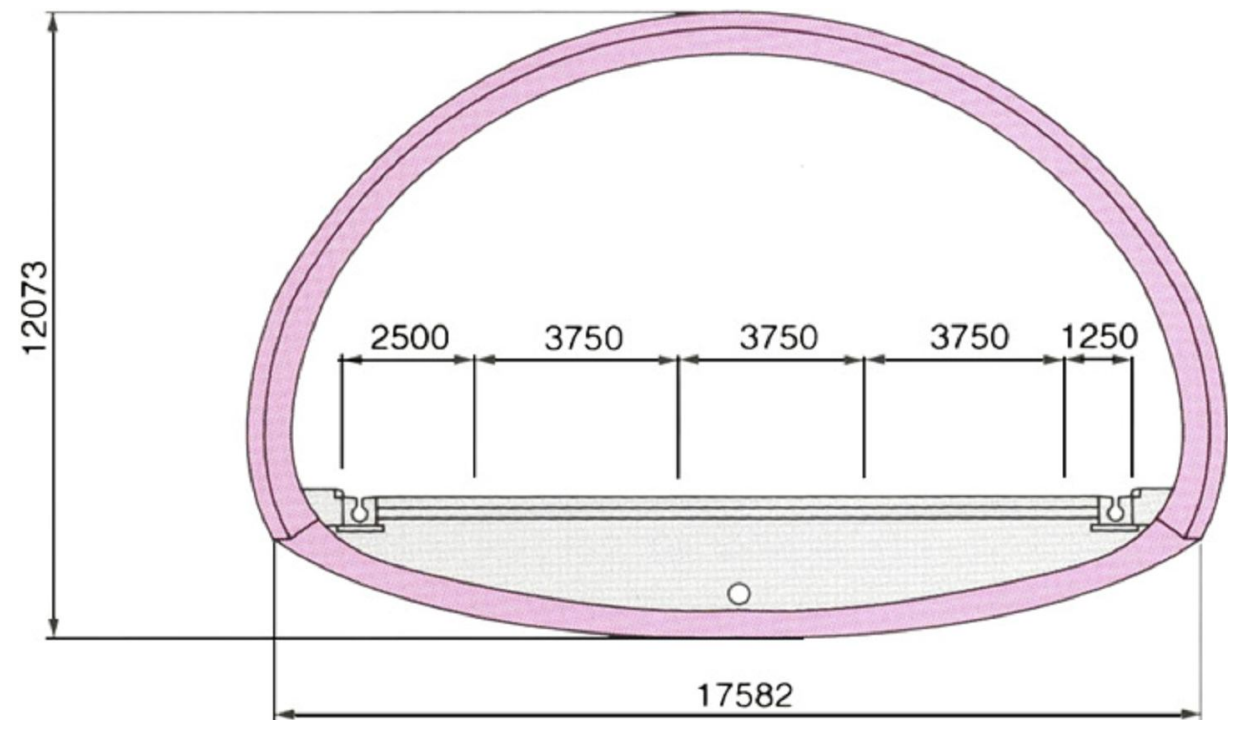

Fig. 2 Standard cross-section used in Shimizu tunnel No.3. 


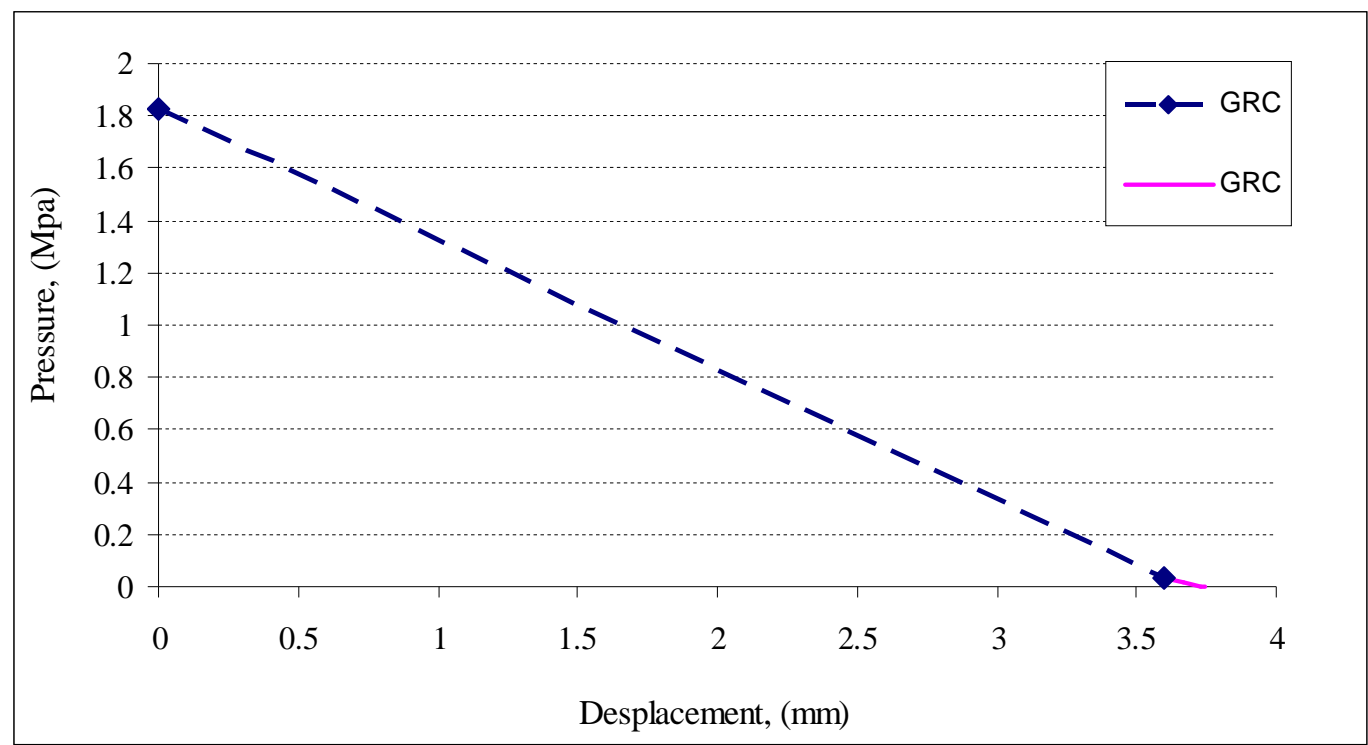

Fig. 3 Ground reaction curve for the Shimizu tunnel

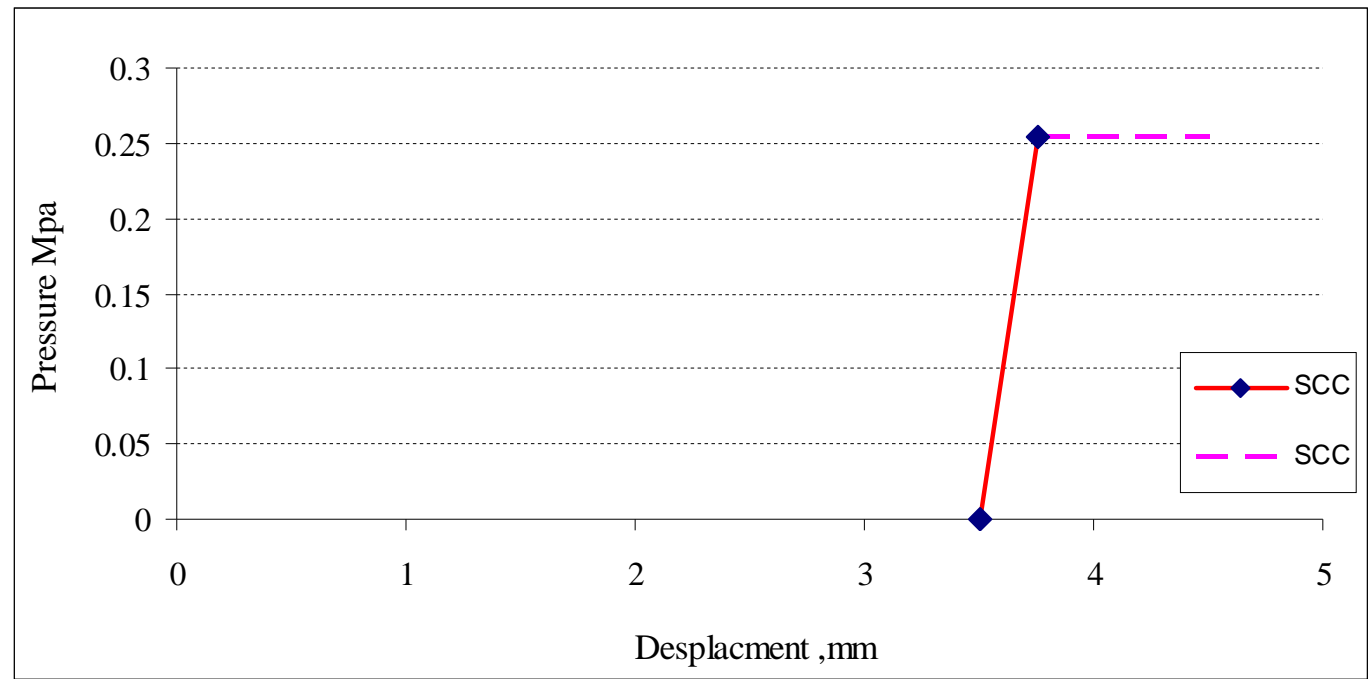

Fig. 4 Support characteristic curve of steel ribs

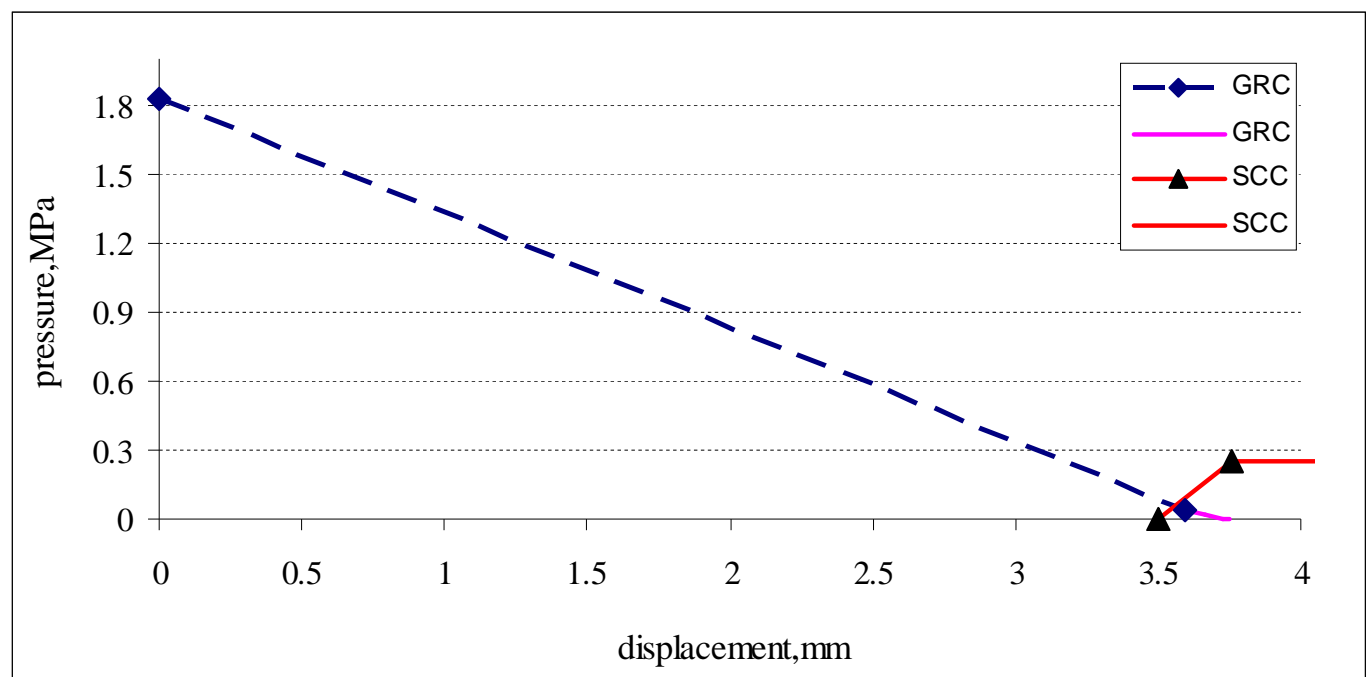

Fig. 5 GRC and support characteristic curve of steel ribs 


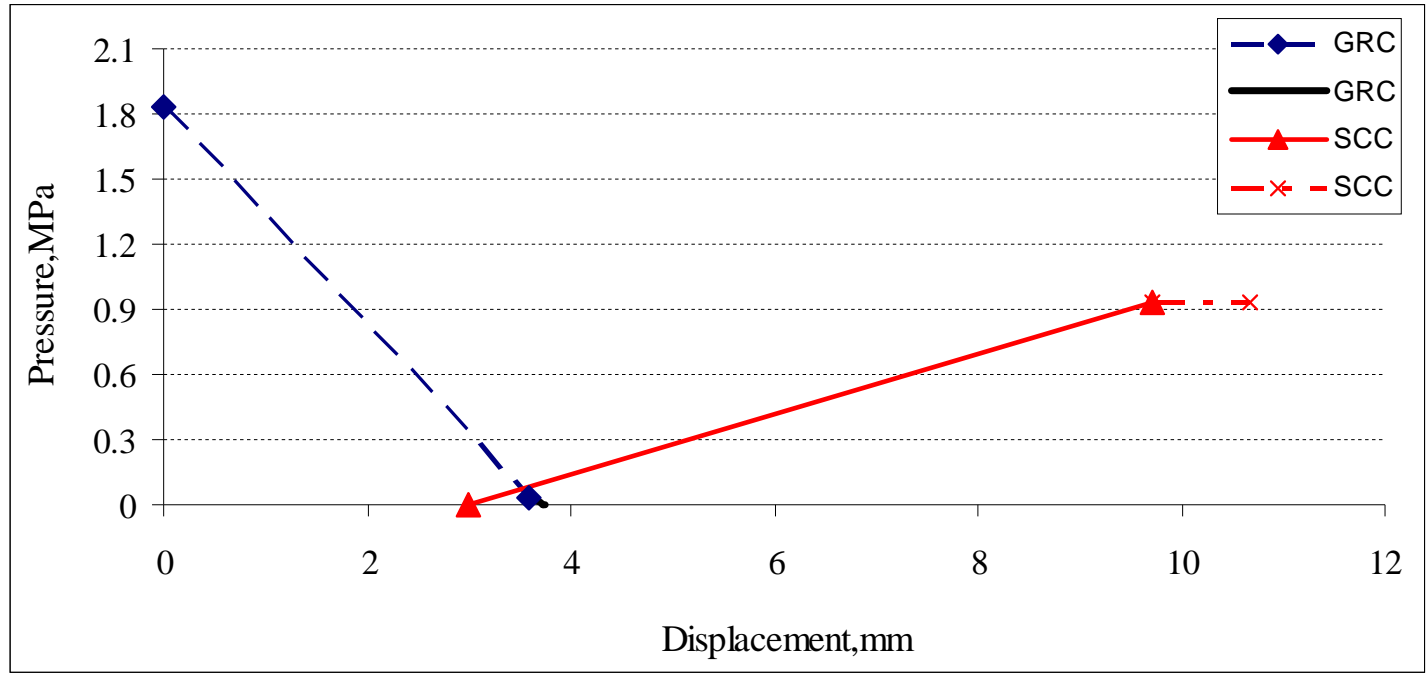

Fig. 6 GRC and support characteristic curve of shotcrete

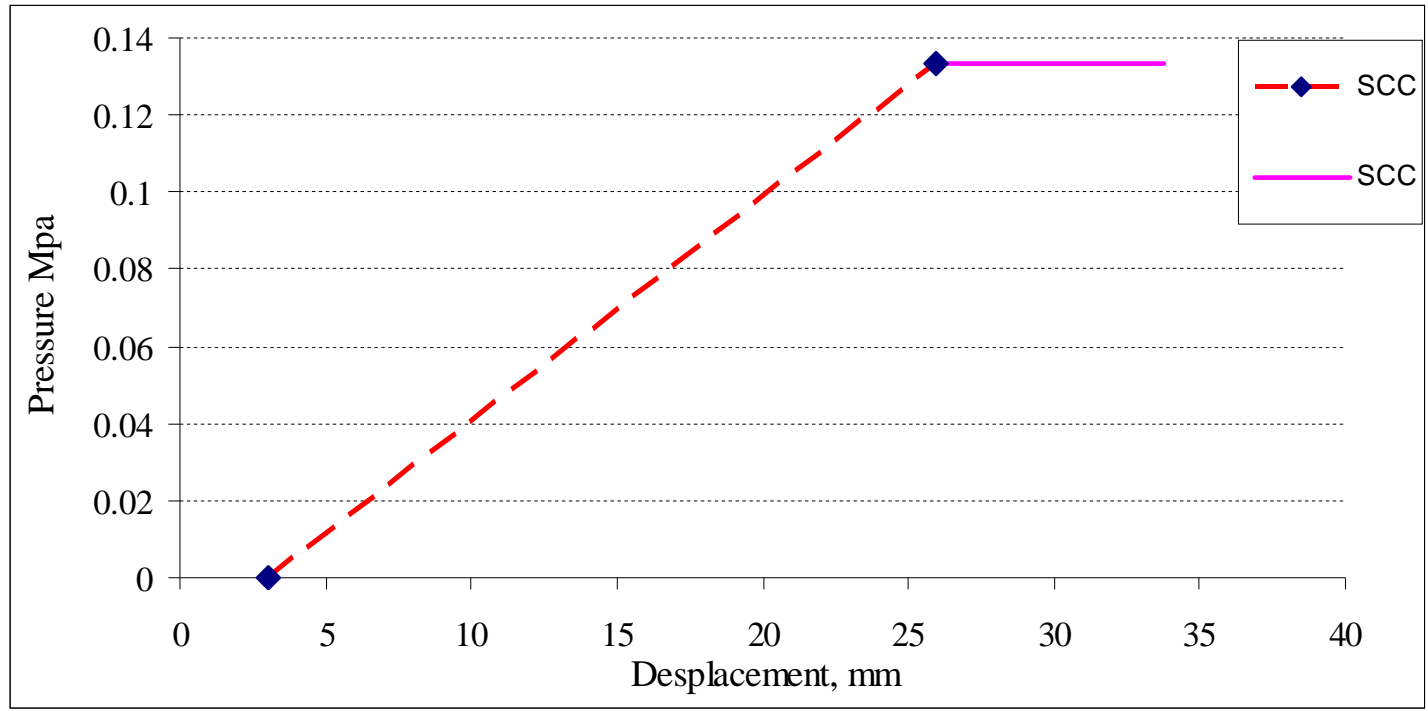

Fig. 7 Support characteristic curve for rock bolts

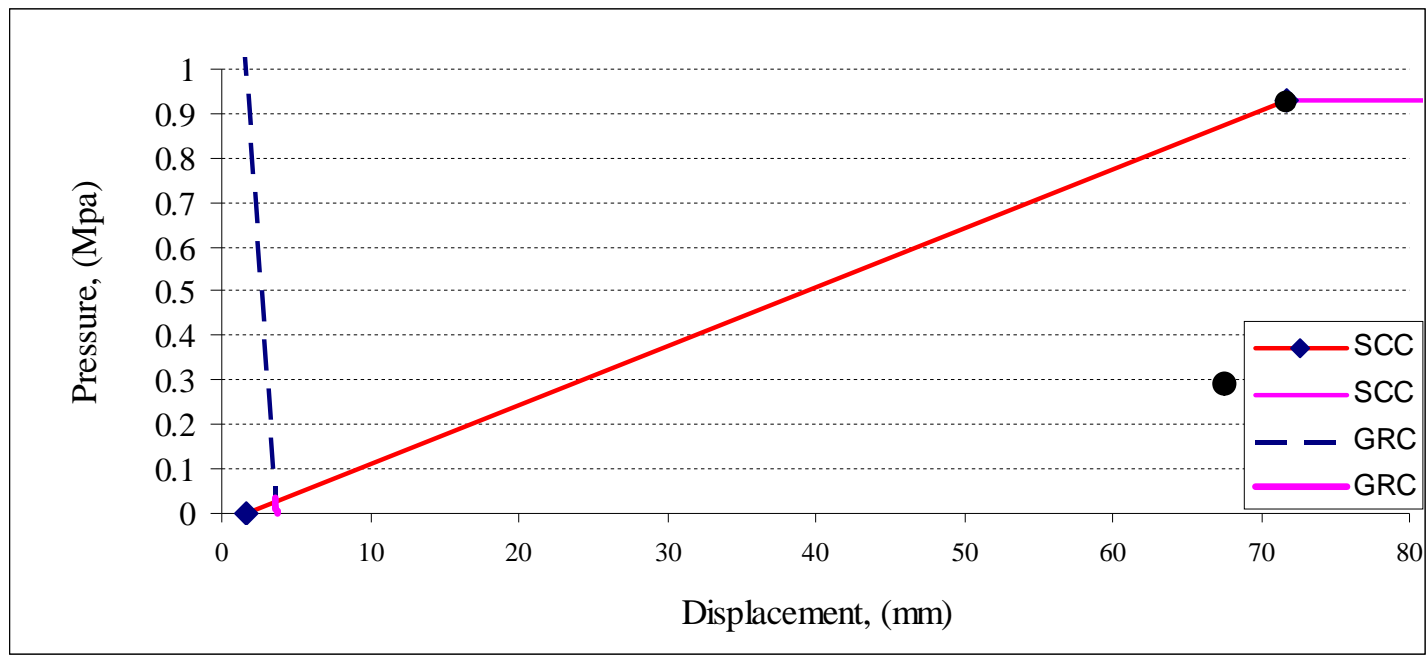

Fig. 8 Support characteristic curve for shotcrete and steel ribs and rock bolts 